\title{
Effect of different cultivation methods on strawberry's antioxidant value
}

\author{
Lálity, Zs. ${ }^{1}$, Borsos, É. ${ }^{2}$, Ficzek, G. ${ }^{3} \&$ Simon, G. ${ }^{3}$ \\ ${ }^{I}$ Educational Centre, Faculty of Horticultural Science, Szent István University, Hungary (e-mail: zsolti7777@ gmail.com) \\ ${ }^{2}$ Teacher Training Faculty in Hungarian in Subotica, University of Novi Sad, Serbia (e-mail: bborsoseva@gmail.com) \\ ${ }^{3}$ Department of Fruit Science, Fauculty of Horticultural Science, Szent István University, Hungary \\ (e-mail: Ficzek.Gitta@kertk.szie.hu,Simon.Gergely@kertk.szie.hu)
}

\begin{abstract}
Summary: The small fruit and strawberry production is economically important in Serbian agriculture. The fresh fruit is sold in domestic markets, but the frozen and processed is mainly sold in foreign markets. The growers find themselves in an ever-expanding selection of the varieties, but besides the nursery and breeder's descriptions of new cultivars, there are only few exact results for the biological and economical ability of the varieties, which makes easier to choose the proper cultivar. The performance of the varieties in modern strawberry production is worth to investigate by adaptive cultivation methods and production technique. In the case of new strawberry varieties we know neither their needs in production nor their real capability, so they have to be compared with an older, standard control variety ('Clery'). The breeder's manuals give only references for the needs of the production technique, of the variety, so it is necessary to have facts, which are based on objective testing results. In this work, a new variety ('Joly') is being compared with the control variety. Comparative study of individual varieties are required covering the antioxidant content of the fruits (FRAP) and variability of these amounts in different years of breeding as well as the production techniques under similar circumstances.
\end{abstract}

Lálity, Zs., Borsos, É., Ficzek, G., Simon, G. (2018): Effect of different cultivation methods on strawberry's antioxidant value. International Journal of Horticultural Science 24(3-4): 7-10. https://doi.org/10.31421/IJHS/24/3-4./2043

Key words: strawberry, cultivation method, FRAP, Serbia

\section{Introduction}

Strawberries are very likely one of the first fruits, which were cultivated by humans Before Christ. Authors from classic era, e.g. Theophrastos from Ancient Greece, Ovid, Pliny, Virgil, from the ancient Rome has been mentioned this fruit as a wild plant and herb.

In the development of today's strawberry (Fragaria ananassa Duch. $\mathrm{F}=$ Grandiflora Ehrh., $2 \mathrm{n}=8 \mathrm{x}=56$ ) the most important moment was the Virginian strawberry $(F$. virginiana Duch. F) and the Chilean strawberry (F. chiloensis Duch. F) spontaneous hybridization in the XVIII. century, in Brest (France). The new strawberry cultivar inherited its red fruit colour from the Virginian strawberry, fruit size and the excellent flavour from Chilean strawberry (Milivojević, 2010).

The strawberry growing becomes more and more important in worldwide relation for population supplying with food, besides the large amounts of carbohydrates and organic materials, contains a significant amount of antioxidants (anthocyanins, phenolic acid, flavones and flavonoids) and A, $\mathrm{E}, \mathrm{C}$ vitamins. Both of these substances help to preserve the human health, circulatory disorders and reduce the formation of cancerous lesions chance (Nikolić, 2010).

The World produced 554 million tons of fruit quantity in 2007. Of this amount, the share of strawberries is $1.05 \%$ or 5.781.678 tons (FAO Production Yearbook, 2014; Turhan \& Paydas-Kargi, 2007).
The strawberry growing covers about 5085 ha in Serbia. The strawberry growing area covers 498 ha in Vojvodina province sharing in $10 \%$ from the total berry area. The average yield in national relation reaches 5 t/ha (Serbian Statistical Yearbook, 2014).

Sturm (2003) has already discovered that consumer satisfaction studies for favourable flavour determined not only by the total sugar content, but also the structure of each sugar, and the ratio is also an important factor. The glucose and fructose predominates to sucrose, the sugar content is increasing parallel from the technological maturity to full maturity direction.

Due to the high content of polyphenols in fruits, they have very good antioxidant effect. In strawberry fruits more anthocyanins, phenolic acid and flavonoids were also detected (Deighton et al., 2002; Scalzo et al., 2005).

Strawberries include a major source of ascorbic acid that being a natural antioxidant which prevents the natural darkening of the fruit skin, and increases shelf life (Lee \& Kader, 2000).

The laboratory tests for the fruit are important, especially the traditional and instrumental analytical tests (titratable acidity, Brix\%, qualitative analysis of sugars and acids, watersoluble antioxidant content - FRAP) (Tulipani et al., 2008).

Geneticists delight annually both growers and consumers with new varieties more and more satisfying, more beautiful 
than ever, more productive and facing many dangerous organism. As a result, the fruit of the strawberry has the fastest type of change among fruits. The novelty value of one new strawberry variety is now estimated just one decade of time (Dénes, 2014).

\section{Materials and methods}

\section{Experimental material}

The applied varieties were 'Clery' and 'Joly'. The first cultivar is treated as control variety and can be compared to the new perspective variety, 'Joly'.

'Clery'. Breed in Italy. It is a patented variety, property of Mazzoni Group, the distributor in Serbia is Agro-Ferticrop Subotica. Parent partners are (El Santa x FBGL 3) x Sweet Charlie. Medium growth, medium-density bush variety, tolerant to foliar and root diseases. Flowers are plenty of pollen producers, frost resistance is good. Its fruits are uniformly large, conical, bright red, very firm, sweet with good taste. It has very early ripening time, depending on the used cultivation system, one or two weeks before the El Santa. Its yield potential is heavily dependent on the type of plants used, over medium-high in case of Frigo seedlings, very high yield strength when planting from seedling trays. 'Clery' is sensitive to the high lime content of the soil according to Hungarian experience (Dénes, 2014). In our experiment it was the control breed.

'Joly'. It is from the breeding program of variety C.I.V. (Italy), from 2009. It is a protected variety, the distributor in Serbia is Agro-Ferticrop Subotica. Ripening time is 3 days after 'Clery'-s; mid-early, long-maturing, high-yielding variety. Blunt cone-shaped, and the size and consistency of the fruit preserves till the end of the ripening. The plant has big, spectacular, reflected bracts. Its fruit is dark red, very flashy and smooth. The meat is red and the skin is equally hard, it can tolerate the hand-picking. It has an excellent flavour and high sugar content and it is also very fragrant. For 'Joly' is especially important the early planting, otherwise the flowers would be too little: plant them into the ground before July 10 . Only first-class flowers are formed on it, so- it has uniformed crop quality. This variety is not sensitive to soil quality, and can widely be cultivated. Requires little nitrogen (in case of surpluses leaves turns white and distorted). This variety is cooled, stored excellent. The flowers are large, well-fertilized. The bush is medium strong growth, tolerant to all soil types. The root system is strong, resistant to root diseases. It has resistance to fungal diseases (slightly more sensitive than 'Clery' to the powdery mildew) (Mišić, 2002; Hotváth, 2013). The capacity of the cultivars at modern strawberry production can be investigated in relation of the production techniques. In our experiment it was the experimental breed.

For the tests A and A- frigo strawberry plants were used taken from Vivai Mazzoni (Italy) company directly through their official distributor in Serbia (Agro-Ferticrop Subotica).

\section{Soil and climate conditions}

The soil parameters of the test strawberry orchard in 2015 are shown in Table 1. The soil analyse was made in the Soil and Agroecology Laboratory of Novi Sad. Laboratory is accredited by ATS (Serbian Accreditation Body) according to the standard SRPS ISO/IEC 17025:2006, certificate number 01-003.

Table 1. The soil parameters of the test strawberry orchard in 2015.

\begin{tabular}{|c|c|c|c|c|c|c|c|}
\hline \multirow{2}{*}{$\begin{array}{l}\text { Culti- } \\
\text { vation } \\
\text { method }\end{array}$} & \multicolumn{2}{|c|}{ pH } & \multirow{2}{*}{$\begin{array}{c}\mathrm{CaCO}_{3} \\
\%\end{array}$} & \multirow{2}{*}{$\begin{array}{c}\text { Org. } \\
\text { leaf } \\
\%\end{array}$} & \multirow{2}{*}{$\begin{array}{l}\text { Total } \\
\text { N \% }\end{array}$} & \multirow{2}{*}{$\begin{array}{c}\mathrm{AL}- \\
\mathrm{P}_{2} \mathrm{O}_{5} \\
\mathbf{m g} / \mathbf{1 0 0 g}\end{array}$} & \multirow{2}{*}{$\begin{array}{l}\mathrm{AL}-\mathrm{K}_{2} \mathrm{O} \\
\mathrm{mg} / 100 \mathrm{~g}\end{array}$} \\
\hline & $\mathrm{KCl}$ & $\mathrm{H}_{2} \mathrm{O}$ & & & & & \\
\hline & 7.6 & 8.59 & 19.02 & 3.23 & 0.221 & 40.6 & 24.2 \\
\hline & \multicolumn{2}{|c|}{ Alkaline } & $\begin{array}{c}\text { Well } \\
\text { carbonated }\end{array}$ & Middle & High & High & Optimal \\
\hline \multirow[b]{2}{*}{2} & 7.35 & 8.24 & 3.21 & 2.96 & 0.195 & 32.2 & 28.9 \\
\hline & \multicolumn{2}{|c|}{ Alkaline } & $\begin{array}{c}\begin{array}{c}\text { Lightly } \\
\text { carbonated }\end{array} \\
\end{array}$ & Middle & Medium & High & High \\
\hline 3 & \multicolumn{7}{|c|}{$\begin{array}{l}\text { TS } 3 \text { AQUASAVE (Klasmann) - for production of vegetable } \\
\text { seedlings. Mixture of white sphagnum peat }(80 \%) \text { and frozen } \\
\text { through black peat }(20 \%) \text { with addition of nutrients } 1.5 \mathrm{~g} / \mathrm{l} \text { and } \\
\text { wetting agent. Very fine structure } 0-5 \mathrm{~mm} \text {. NPK }-14: 14: 18, \mathrm{pH}-6\end{array}$} \\
\hline
\end{tabular}

\section{Cultivation methods}

Three different cultivation methods are mostly applied spread in Vojvodina (Serbia). These are as follows:

1. Open field as single and double-row cropping system.

2. Plastic greenhouse without heating as single and double-row cropping system.

3. Plastic greenhouse without heating in vertical growing equipment filled with peat as the culture medium.

The three cultivation methods that listed above were examined in this study and the outcomes of cultivation methods at two varieties ('Clery', 'Joly').

Investigations were performed in the spring (May) of 2016 and 2017 around town Senta (Vojvodina) in three location simultaneously, depending on the different production technologies.

The plants were planted in 25.07.2015. Drip irrigation was used (drip tape) to water the strawberry plants, also to dispatch the fertilizer correctly. The threats are shown in Table 2. Carried out plant protection works were as follows in Table 3.

Table 2. Fertilization plan.

\begin{tabular}{|c|c|}
\hline Date & Treatment \\
\hline 15.03 & Yara Starter 15-30-15 \\
\hline 22.03 & YaraLiva $^{\mathrm{TM}}$ Calcium \\
\hline 29.03 & Ferticare $^{\mathrm{TM}} 14-11-25$ \\
\hline 05.04 & YaraVita $^{\mathrm{TM}}$ Rexolin $(\mathrm{Fe})$ \\
\hline 12.04 & Ferticare $^{\mathrm{TM}} 14-11-25$ \\
\hline 19.04 & YaraKrista MAG $(\mathrm{Mg})$ \\
\hline 26.04 & Ferticare $^{\mathrm{TM}} 14-11-25$ \\
\hline 02.05 & YaraLiva $^{\mathrm{TM}}$ Calcium \\
\hline 09.05 & Ferticare $^{\mathrm{TM}} 14-11-25$ \\
\hline 16.05 & Krista K+ \\
\hline 23.05 & Krista $\mathrm{K}+$ \\
\hline 30.05 & Krista SOP \\
\hline
\end{tabular}


Table 3. Plant protection plan.

\begin{tabular}{|c|c|c|}
\hline Date & Active ingredient (trade name) & Pest definition \\
\hline \hline 02.10 & iprodione (Rovral) & Mycospherella fragariae \\
\hline 20.03 & thiofanat-methyl (Funomil) & Rhizoctonia fragariae \\
\hline 10.04 & copper oxychloride & common leaf spot \\
\hline 15.04 & boscalid+pyraclostrobin (Signum) & Botrytis cinerea \\
\hline 20.04 & methomyl (Lannate) & Tropinota hirta \\
\hline 30.04 & procymidone (Sumilex) & Botrytis cinerea \\
\hline 04.05 & chlorpyrifos+cipermethrin (Konzul) & Frankliniella occidentalis \\
\hline 15.05 & deltamethrin (Decis) & Aphis forbesi \\
\hline 20.05 & fenhexamid (Teldor) & Botrytis cinerea \\
\hline 30.05 & cyprodinil+fludioxonil (Switch) & Botrytis cinerea \\
\hline 10.06 & abamectin (Abastate) & Frankliniella occidentalis \\
\hline
\end{tabular}

\section{Sample preparation}

The fruit was picked once at the ripening stage of $90 \%$. In case of the three cultivation method the selected sample consisted of 10 plants per field. The tests were repeated in 2016 and in 2017.

The samples (2 kg/cultivars) were homogenized after picking in a blender and stored in the freezer at $-28{ }^{\circ} \mathrm{C}$ until analysis. After defrosting and centrifugation; samples were taken from the supernatant refraction. We examined the physicochemical parameters and water soluble antioxidant capacity (FRAP) in 3 replicates.

\section{The ferric reducing/antioxidant power (FRAP) assay}

The ferric reducing/antioxidant power (FRAP) assay was carried out according to Benzie and Strain (1996). The FRAP assay is based on the reduction of the $\mathrm{Fe}^{3+-} 2,4,6$-tripyridyl-Striazine complex to the ferrous form $\left(\mathrm{Fe}^{2+}\right)$ and the intensity of the reaction is monitored by measuring the change of absorption at $593 \mathrm{~nm}$.

\section{Statistics}

Statistical analyses were performed using SPSS 22.0 statistical software package.

\section{Results and discussion}

In 2016 in the case of the control breed 'Clery' the highest antioxidant average value was found applying plastic greenhouse cultivating technology: $24.87 \mathrm{mM} / 1( \pm 0.38)$. The result in the case of vertical cultivating technology was $23.64 \mathrm{mM} / 1( \pm 0.61)$. In the case of open field cultivating technology the antioxidant value was significantly lower: $8.70 \mathrm{mM} / 1( \pm 0.37)$.

In 2016 in the case of the experimental breed 'Joly' the highest antioxidant value was found applying vertical cultivating technology: $25.55 \mathrm{mM} / 1 \quad( \pm 0.25)$. The result in plastic greenhouse cultivating technology was $25.32 \mathrm{mM} / 1$ $( \pm 0.13)$. In the case of open field cultivating technology the antioxidant value was significantly lower: $10.03 \mathrm{mM} / 1( \pm 0.27)$.

Comparing the two breeds significant differences were found in the case of all three cultivating technologies $(p=0.000)$. In the case of vertical, plastic greenhouse and open field technology also the breed 'Joly' showed better results (Figure 1).

In 2017 in the case of the control breed 'Clery' the highest antioxidant average value was found applying open field cultivating technology: $40.87 \mathrm{mM} / 1( \pm 1.69)$. The antioxidant average value was a little bit lower in the case of vertical cultivating technology: $25.69 \mathrm{mM} / 1( \pm 0.91)$. In the case of plastic greenhouse cultivating technology the antioxidant value was significantly lower: $16.97 \mathrm{mM} / 1( \pm 1.51)$.

In 2017 in the case of the experimental breed 'Joly' the highest antioxidant average value was found applying open field cultivating technology: $43.37 \mathrm{mM} / 1 \quad( \pm 0.79)$. The antioxidant average value was a little bit lower in the case of vertical cultivating technology: $30.11 \mathrm{mM} / 1( \pm 1.85)$. In the case of plastic greenhouse cultivating technology the antioxidant value was significantly lower: $28.69 \mathrm{mM} / 1( \pm 0.91)$.

Comparing the two breeds significant differences were found in the case of all three cultivating technologies $(p=0.000)$. In the case of vertical, plastic greenhouse and open field technology also the breed 'Joly' showed better results (Figure 2).

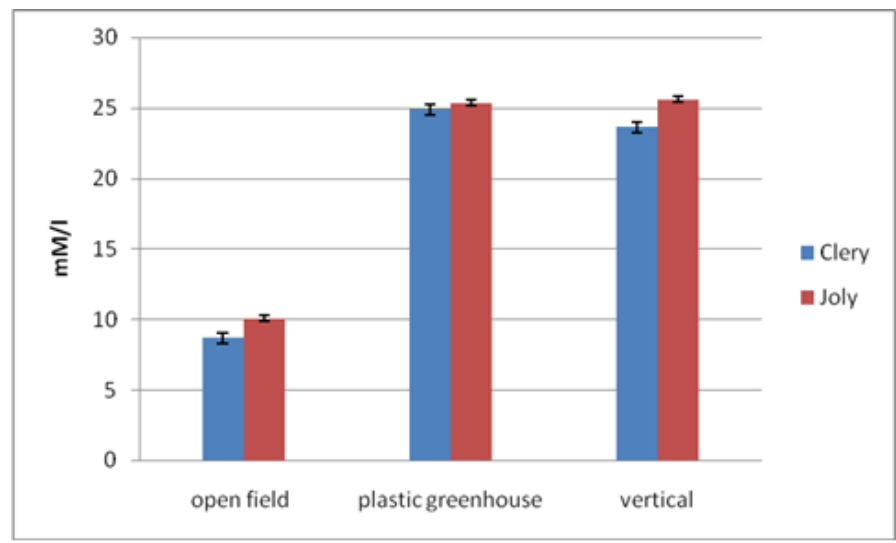

Figure 1. The average antioxidant values in 2016 in the case of the three cultivation technologies.

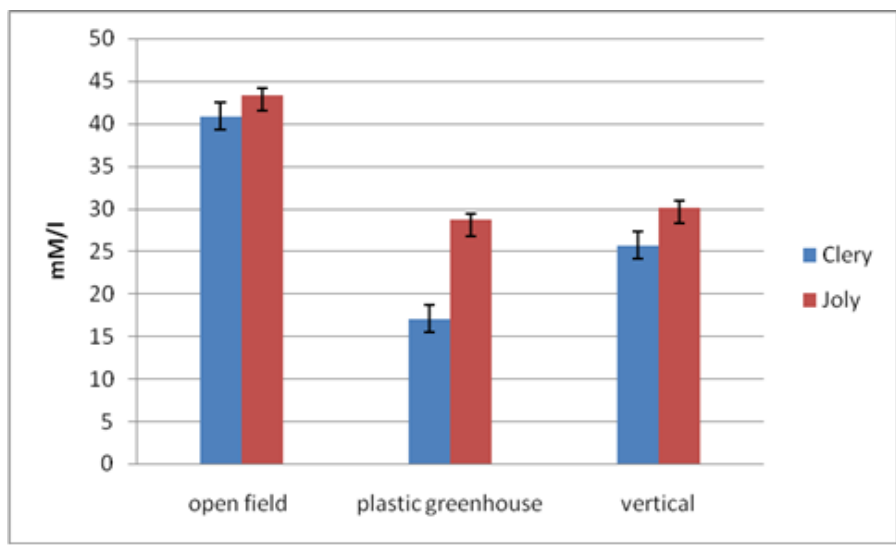

Figure 2. The average antioxidant values in 2017 in the case of the three cultivation technologies.

Comparing the results got in 2016 and 2017 significant differences were found in the case of all three cultivating technologies in the case of two breeds $(p=0.000)$. In the case of vertical, plastic greenhouse and open field technology and in the case of the control breed 'Clery' and the experimental breed 'Joly' the year 2017 showed better results. 


\section{Discussion}

Both varieties are early ripening, the experimental breed 'Joly' comes a few days later than the control breed 'Clery'. In Serbia the ripening period starts in the first decade of May (in plastic greenhouses around seven-ten days earlier) and it lasts approximately three weeks.

There are a significant difference between antioxidant content of the fruits because the experimental breed 'Joly' significantly outperforms the control variety for all three cultivation methods of breeding for both years of examination.

In 2016 in the case of the experimental breed 'Joly' the highest antioxidant value was found applying vertical cultivating technology: $25.55 \mathrm{mM} / 1( \pm 0.25)$.

In 2017 in the case of the experimental breed 'Joly' the highest antioxidant average value was found applying open field cultivating technology: $43.37 \mathrm{mM} / 1( \pm 0.79)$.

Comparing the two age groups (2016 and 2017) the weather conditions were slightly different (rainfall difference is 120 $\mathrm{mm}$ plus in the whole vegetation period in 2016, the air temperature, humidity were the same in both years).

Comparing the results got in 2016 and 2017 significant differences were found in the case of all three cultivating technologies in the case of two breeds $(p=0.000)$. In the case of vertical, plastic greenhouse and open field technology and in the case of the control breed 'Clery' and the experimental breed 'Joly' the year 2017 showed better results.

\section{References}

Bartoletti, L. (1998): Ulteriori studi sulla suscettibilita varietale ad alcuni patogeni della fragola. Frutticoltura. 5: 5762.

Benzie, I. I. F., Strain, J. J. (1996): The Ferric Reducing Ability of Plasma (FRAP) as a measure of ,antioxidant power". The FRAP assay. Annal. Biochem. 239: 70-76.

Dénes, F. (2014): Szamócatermesztés, Mezőgazda Kiadó Budapest, pp. 9-14, 66-69.

Dominguez, M. (2008): The strawberry crop at Huelva: The geographical setting of strawberry fields, Autonomus Ministry of Agriculture and Fisheries, Spain. pp. 207-212.

Deighton, N., Stewart, D., Davies, H. V., Gardner, P. T, Duthie, G. G., Mullen, W., Crozier, A. (2002): Soft fruit as sources of dietary antioxidants. Acta Horticulturae 585: 459465. https://doi.org/10.17660/ActaHortic.2002.585.74
Horváth, Cs. (2013): Szamócatermesztési tanácsok. Kertészet és Szőlészet. 62(23): 18-20.

Lee, K. S., Kader, A. A (2000): Preharvest and posthervest factors influencing vitamin $\mathrm{C}$ content of horticultural crops. Postharvest Biology and Technology 20: 207-220. https://doi.org/10.1016/S0925-5214(00)00133-2

Milivojević, J. M. (2010): Jagoda. Naučno voćarsko društvo Srbije, Čačak, pp. 14-15.

Mišić, P. D. (2002): Specijalno oplemenjivanje voćaka. Institut „Srbija“ i Prtenon Beograd. pp 11-13.

Nikolić, M. D. (2010): Jagodaste voćke. Naučno voćarsko društvo Srbije, Čačak, pp. 43-46.

Šoškić, M. (1997): Jagoda, partenon, Beograd, pp 27-28.

Shuping, Y., Larson K. D. (2009): Strawberry industry in China. Acta Hortculturae 842: 619-622. https://doi.org/10.17660/ActaHortic.2009.842.132

Simon, G. (2009): Szamóca. In: Tóth Magdolna (szerk): Gyümölcs faj és faj- és fajtaismeret egyetemi jegyzet. Budapesti Corvinus Egyetem Kertészettudományi Kar, Budapest. pp. 18-21.

Scalzo, J., Politi, A., Pellegrini, N. (2005): Plant genotype affects total antioxidant capacity and phenolic contents in fruit. Nutrition 21(2): 207-213., DOI: 10.1016/j.nut.2004.03.025

Sturm, K. (2003): The composition of fruit of different strawberry varieties depending on maturity stage. Food Chemistry. 83: 417-422.

Tulipani, S., Mezzeti, B., Capocasa, F., Bompadre, S., Beekwilder, J, De Vos C. H., Capanoglu, E., Bovy, A., Battino, M. (2008): Antioxidants, Phenolic Compounds, and Nutritional Quality of Different Strawberry Genotypes. Journal of Agricultural and Food Chemistry. 56(3): 696-704. doi: 10.1021/jf0719959

Turhan, E., Paydas-Kargi, S. (2007): Strawberry production in Turkey. Chronica Horticulturae 47(2): 18-20.

FAO production Yearbook (2014): http://www.fao.org/3/ai3621e.pdf, pp 34-37.

\section{Serbian Statistical Yearbook} http://ebooks.ien.bg.ac.rs/189/

Statistički Godišnjak (2014) (Statistical yearbook of the Republic of Serbia, 2014. Belgrade, ISSN 0351-4064) http://pod2.stat.gov.rs/ObjavljenePublikacije/God/SGS2014.pd f, pp 219-224. 